\title{
The protective effects of ketamine and propofol in obstructive jaundice: an experimental study
}

\author{
Yildiz $\mathrm{H}^{1}$, Coskuner $\mathrm{I}^{1}$, Bulbuloglu $\mathrm{E}^{2}$, Silay $\mathrm{E}^{1}$, Kurutas $\mathrm{EB}^{3}$, Dogan $\mathrm{Z}^{2}$, Kantarceken $\mathrm{B}^{4}$, \\ Oksuz $\mathrm{H}^{1}$, Senoglu $\mathrm{N}^{1}$, Yuzbasioglu $\mathrm{MF}^{2}$, Cetinkaya $\mathrm{A}^{4}$, Ciralik $\mathrm{H}$
}

Department of Anesthesiology, KSU, Faculty of Medicine, Kahramanmaras, Turkey. Ertanbulbuloglu@yahoo.com.t

\begin{abstract}
Objective: In this study, we investigated the protective effects of frequently used intravenous anesthetics (ketamine, propofol, thiopental, and fentanyl) in oxidative stress in a rat liver model of obstructive jaundice. Materials and methods: Thirty-two Wistar albino rats were divided into four groups in a randomized fashion. All rats were subjected to laparotomy, common bile duct ligation and severance on day 0 . Following 7 days, laparotomy was again performed using ketamine, propofol, pentobarbital, or fentanyl anesthesia. After 2 hours, the animals were sacrificed and tissue specimens were acquired for histopathological scoring and determination of malondialdehyde (MDA), superoxide dismutase (SOD) and catalase (CAT) activities.

Results: All rats demonstrated enlargement in the bile duct, obstructive jaundice, and histopathologic ductal proliferation. MDA and SOD levels were significantly lower in the ketamine group compared with the thiopental and fentanyl groups. CAT was significantly increased in the ketamine group compared with the other groups. The best portal polymorphonuclear leukocyte and necrosis scores were in the ketamine group, but this difference was not statistically significant $(p=0.07)$

Conclusion: Ketamine and propofol were observed to cause the least amount of oxidative stress in this rat model of induced oxidative stress generated by ligation of the common bile duct. This experiment is the first study on this subject in the literature (Tab. 3, Ref. 65). Full Text in PDF www.elis.sk.

Key words: ketamine, propofol, common bile duct, rat.
\end{abstract}

Obstructive jaundice can be induced in the rat by common bile duct ligation (CBDL), which causes parenchymal cell damage that may ultimately lead to liver cirrhosis and portal hypertension (1). Tissue injury induced by obstructive jaundice involves lipid peroxidation (2). Most CBDL animals have been shown to be deficient in fat-soluble vitamins, such as vitamins A and E (3). Because these vitamins are capable of ameliorating secondary tissue damage induced by lipid peroxidation, enhanced oxidative stress could possibly exacerbate secondary tissue damage. Moreover, obstructive jaundice could alter the activities of antioxidant enzymes resulting in increased production of superoxide $\left(\mathrm{O}_{2} \bullet\right)$ and hydrogen peroxide $\left(\mathrm{H}_{2} \mathrm{O}_{2}\right)$ (4). As a result, hydroxyl radicals $(\bullet \mathrm{OH})$ form through the interplay between $\mathrm{O}_{2} \cdot \mathrm{H}_{2} \mathrm{O}_{2}$, and iron via the Haber-Weiss (1) or Fenton (2) reactions (2-5).

Patients with obstructive jaundice are often subjected to either general or sedation anesthesia, usually using drugs which are metabolized and/or eliminated by the liver. Intravenous agents

${ }^{1}$ Department of Anesthesiology, KSU, Faculty of Medicine, Kahramanmaras, Turkey, ${ }^{2}$ Department of General Surgery, KSU, Faculty of Medicine, Kahramanmaras, Turkey, ${ }^{3}$ Department of Biochemistry, KSU, Faculty of Medicine, Kahramanmaras, Turkey, and ${ }^{4}$ Department of Gastroenterology, General Surgery, KSU, Faculty of Medicine, Kahramanmaras, Turkey

Address for correspondence: E. Bulbuloglu, MD, PhD, Department of General surgery, Faculty of Medicine, Kahramanmaras Sutcuimam University, Kahramanmaras, Turkey 46050.

Phone: +90.344.2212337, Fax: +90.344.2212371 commonly used have been shown to increase oxygen production and generate tissue damage in the liver (6-9). On the other hand, intravenous anesthetic drugs are also capable of reducing oxidative stress (10). In this study, we investigated the effects of frequently used intravenous anesthetics (ketamine, propofol, pentobarbital, and fentanyl), in a rat model of oxidative stress caused by obstructive jaundice through common bile duct ligation.

\section{Materials and methods}

Animals

The experimental protocol was approved by the Animal Ethics Review Committee of the Faculty of Medicine, University of Kahramanmaras and adhered to the National Institutes of Health Guidelines for the Use of Experimental Animals. Thirty-two male Wistar rats were housed in individual cages in a temperaturecontrolled room with alternating 12-hour light-dark cycles, and acclimatized for one week before the study commenced. Animals were allowed free access to water and rat chow.

\section{Experimental design}

In this prospective experimental study, rats were divided randomly into four groups, each group containing eight animals. Food was witheld 12 hours before the operation, with water ad libitum during this period. Each rat was weighed and anaesthetized with ketamine $(50 \mathrm{mg} / \mathrm{kg})$ intramuscularly. As described by Lee in their 
model of experimental jaundice created by ligation of the common bile duct (11), following a midline incision, the common bile duct was exposed and a double-ligature was placed around the duct with a 5-0 silk suture. The bile duct was then transected between the ligatures and the abdominal wall was closed with 3-0 silk in two layers.

Seven days later, Group I received intramuscular ketamine $(50 \mathrm{mg} / \mathrm{kg})$, Group II received intramuscular propofol $(10 \mathrm{mg} /$ $\mathrm{kg}$ ), Group III received intramuscular pentobarbital $(20 \mathrm{mg} / \mathrm{kg})$, and Group IV received intramuscular fentanyl $(50 \mathrm{mcg} / \mathrm{kg})$. Two hours later, the rats were sacrificed.

\section{Sample collection}

The animals were anaesthetized and a second laparotomy was performed. The liver was carefully dissected from its attachment and totally excised. The liver was flushed with physiological saline and then cut into two pieces, one of which was immediately frozen in liquid nitrogen and stored at $-80{ }^{\circ} \mathrm{C}$ for later measurement of malondialdehyde (MDA), superoxide dismutase (SOT) and catalase (CAT) activities.

\section{Histopathological evaluation}

Liver fragments were kept in $10 \%$ formaldehyde solution for 6-48 h. Following treatment with alcohol and xylene, specimens were embedded in paraffin blocks. After preparation, the sections were stained with hematoxylin and eosin. Pathological examination of portal mono- and polymorphonuclear leukocytes, ductal proliferation, and hepatic necrosis were made by a pathologist blinded to treatment group. Each of the histopathological parameters listed in Table 1 were evaluated and scored for each slide: 0 for no change, 1 for mild, 2 for moderate, and 3 for severe changes. The histopathological parameters were expressed as the minimum-median-maximum (Tab. 2).

\section{Antioxidant study}

In order to determine tissue antioxidant levels, $1 \mathrm{x} 1 \mathrm{~cm}^{2}$ tissue samples were removed from the freezer, brought to room temperature, then homogenized with three volumes of ice-cold
$1.15 \% \mathrm{KCl}$. Activities of antioxidant enzymes and levels of lipid peroxidation were measured in the supernatant after centrifugation at 14,000 rpm. SOD activity was measured by the method described by Fridovich (12). CAT activity was determined by measuring the decrease in hydrogen peroxide concentration at $230 \mathrm{~nm}$ by the method of Beutler (13). Lipid peroxidation was reflected by MDA levels, which were measured by the method described by Ohkawa et al (14). Protein concentrations were determined by the method of Lowry (15).

\section{Statistical analysis}

Histopathological data were expressed as the minimummedian-maximum. Tissue antioxidant levels were expressed as mean \pm standard deviation. The Kolmogorov-Smirnov statistic was used to test the normality of distributions.

Differences between SOD groups were evaluated by Kruskal-Wallis variance analysis followed by a post-hoc ( Bonferroni correction ) Mann-Whitney U test. Differences between MDA and CAT groups were evaluated by ANOVA for continuous variables with post-hoc procedures (Bonferroni correction). $\mathrm{P}$ values less than 0.05 were considered statistically significant. Data were analyzed using the SPSS 9.05 for Windows ${ }^{\circledR}$ statistical package.

\section{Results}

All animals survived without complications until the end of the experiment.

Although the mean histopathologic score was lower in the ketamine group, this was not significantly lower than the scores of the propofol, pentobarbital, and fentanyl groups (Tab. 1 and 2).

Regarding markers of oxidative stress, MDA was found to be significantly lower in the ketamine group than in the thiopental $(p=0.005)$ and fentanyl $(p=0.03)$ groups. Although MDA was lower in the ketamine group than in the propofol group, this difference was not statistically significant $(p=0.3$ ). MDA was also lower in the propofol group than in the thiopental group $(\mathrm{p}=0.007$.) MDA was similar between the propofol and fentanyl groups and between the thiopental and fentanyl groups (Tab. 3).

Tab. 1. Numbers of rats (out of 8 in each group) receiving scores $(0=$ none, $1=$ mild, $2=$ moderate, $3=$ severe) of histopathologic injury and necrosis in rats receiving ketamine, propofol, pentobarbital, or fentanyl one week after undergoing common bile duct ligation.

\begin{tabular}{|c|c|c|c|c|c|c|c|c|c|c|c|c|c|c|c|c|}
\hline & \multicolumn{4}{|c|}{ Ketamine } & \multicolumn{4}{|c|}{ Propofol } & \multicolumn{4}{|c|}{ Thiopental } & \multicolumn{4}{|c|}{ Fentanyl } \\
\hline & 0 & 1 & 2 & 3 & 0 & 1 & 2 & 3 & 0 & 1 & 2 & 3 & 0 & 1 & 2 & 3 \\
\hline Portal Polymorphonuclear Leukocytes & 4 & 4 & - & - & 3 & 4 & 1 & - & 2 & 4 & 2 & - & 3 & 3 & 2 & - \\
\hline Portal Monomorphonuclear Leukocytes & 5 & 3 & - & - & 4 & 4 & - & - & 3 & 3 & 2 & - & 4 & 3 & 1 & - \\
\hline Ductular proliferation & - & 2 & 6 & - & - & 3 & 5 & - & - & 3 & 5 & - & - & 2 & 6 & - \\
\hline Necrosis & 6 & 1 & 1 & - & 4 & 3 & 1 & & 3 & 2 & 3 & & 3 & 3 & 2 & \\
\hline
\end{tabular}

Tab. 2. The histopathological parameters expressed as the minimum-median-maximum.

\begin{tabular}{|c|c|c|c|c|c|}
\hline & \multicolumn{5}{|c|}{ Groups } \\
\hline & $\begin{array}{l}\text { Ketamine } \\
\text { Min-M-Max }\end{array}$ & $\begin{array}{l}\text { Propofol } \\
\text { Min-M-Max }\end{array}$ & $\begin{array}{l}\text { Thiopental } \\
\text { Min-M-Max }\end{array}$ & $\begin{array}{l}\text { Fentanyl } \\
\text { Min-M-Max }\end{array}$ & $\mathrm{P}$ value \\
\hline Portal Polymorphonuclear Leukocytes & $0-0.5-1$ & $0-1-2$ & $0-1-2$ & $0-1-2$ & 0.574 \\
\hline Portal Monomorphonuclear Leukocytes & $0-0-1$ & $0-0.5-1$ & $0-1-2$ & $0-0.5-2$ & 0.601 \\
\hline Ductular proliferation & $1-2-2$ & $1-2-2$ & $1-2-2$ & $1-2-2$ & 0.905 \\
\hline Necrosis & $0-0-2$ & $0-0.5-2$ & $0-1-2$ & $0-1-2$ & 0.409 \\
\hline
\end{tabular}


Tab. 3. Mean malondialdehyde (MDA), superoxide dismutase (SOD) levels and catalase (CAT) levels in rats (8 rats in each group) receiving ketamine, propofol, pentobarbital, or fentanyl one week after undergoing common bile duct ligation.

\begin{tabular}{|c|c|c|c|c|}
\hline & \multicolumn{4}{|c|}{ Groups } \\
\hline & Ketamine & Propofol & Pentobarbital & Fentanyl \\
\hline & Mean \pm SD & Mean \pm SD & Mean \pm SD & Mean \pm SD \\
\hline MDA & $0.44 \pm 0.16^{\mathrm{a}, \mathrm{b}}$ & $0.51 \pm 0.12^{\mathrm{c}}$ & $0.79 \pm 0.19$ & $0.74 \pm 0.28$ \\
\hline SOD & $5.58 \pm 1.06^{\mathrm{a}}$ & $7.23 \pm 1.69$ & $7.18 \pm 2.76$ & $8.05 \pm 3.57$ \\
\hline CAT & $201.4 \pm 28.0^{\mathrm{a}, \mathrm{b}, \mathrm{c}}$ & $166.5 \pm 22.0$ & $144.6 \pm 32.5$ & $152.75 \pm 61.51$ \\
\hline
\end{tabular}

MDA: Malondialdehyde, ${ }^{a}, p=0.005$ in ketamine vs pentobarbital, ${ }^{b} \mathrm{p}=0.03$ in ketamine vs. fentanyl, ${ }^{\mathrm{c}}, \mathrm{p}=0.007$ in Propofol vs pentobarbital comparisons, SOD: Superoxide dismutase, ${ }^{\mathrm{a}} \mathrm{p}=0.03$ in ketamine vs propofol, CAT: Catalase, ${ }^{\mathrm{a}} \mathrm{p}=0.02$ in ketamine vs propofol, ${ }^{\mathrm{b}} \mathrm{p}=0.007$ in ketamine vs pentobarbital, ${ }^{\mathrm{c}} \mathrm{p}=0.06 \mathrm{ketamine}$ vs pentobarbital

SOD activity was significantly lower in the ketamine group compared to the propofol group ( $\mathrm{p}=0.03$ ). No other significant intergroup difference was found (Tab. 3).

CAT was significantly higher in the ketamine group compared to the propofol $(\mathrm{p}=0.02)$, thiopental $(\mathrm{p}=0.007)$, and fentanyl $(\mathrm{p}=0.06)$ groups. No other significant intergroup difference was found (Tab. 3).

\section{Discussion}

Biliary obstruction is associated with an intense state of oxidative stress. Antioxidant defenses (as demonstrated by SOD and CAT activities) are decreased and lipid peroxidation (as demonstrated by MDA levels) are increased in the liver during extrahepatic BDL in rat models (16). Liver damage associated with obstructive jaundice in BDL may be caused by accelerated generation of hydroxyl radicals (17).

Some intravenous anesthetic agents have been shown to increase production of reactive oxygen species and cause tissue damage (6-9). Intravenous anesthetic agents generate free radicals by altering intracellular cytochrome $\mathrm{p} 450$, peroxisomes, and enzymatic systems in the mitochondria (6). Moreover, they consume and inhibit enzymatic and non-enzymatic systems that protect the cells via scavenging free radicals. They cause lipid peroxidation, DNA damage and changes in proteins by inducing oxidative damage, which may lead to alterations in cellular functions such as reduced gap junction-mediated transmission, activation of transcription factors (AP-1, NF-kB), intracellular calcium and $\mathrm{pH}$ changes, and/or cell death $(6-9,18)$. Intravenous anesthetic agents have also been shown to cause a decrease in hepatic blood flow $(19,20)$, up to a $30 \%$ decrease in the absence of any surgery in healthy individuals $(21,22)$. In addition, these agents may lead to hypercapnia or global hypoxia for various reasons during anesthesia. In all the ways listed above, these agents increase oxidative damage (23).

To date, no one has reported the effects of anesthetic agents on oxidative stress in rats with obstructive jaundice. In this study therefore, we used intravenous anesthetics (ketamine, propofol, pentobarbital, and fentanyl) whose antioxidative properties are well known.

Ketamine is an N-Methyl-D-aspartate (NMDA) receptor antagonist that has been extensively studied as a safe and reliable dissociative sedative/anesthetic agent in various clinical situations. It possesses novel analgesic and anti-inflammatory properties (24) and has protective properties on ischemic/reperfusion injury of the brain, kidney, skeletal muscle, heart, and intestine (25-29). In the present study, MDA levels were lower and CAT activities higher in the ketamine group compared to the other groups, confirming ketamine's properties as an agent which protects against oxidative stress. SOD activities were also significantly lower in the ketamine group than in the propofol group. The lower SOD activity in the ketamine group was thought to be due to an adequate reduction of superoxide radicals, whereas the increase in CAT activity was associated with higher peroxide concentration. Since ketamine lowered MDA levels more than the other agents, we can surmise that it has an influence over the antioxidant defense system, while reducing lipid peroxidation. SOD catalyzes the produced superoxide radicals into $\mathrm{H}_{2} \mathrm{O}_{2}$, whereas CAT prevents oxidative damage by dissociating $\mathrm{H}_{2} \mathrm{O}_{2}$ and inhibiting lipid peroxidation.

Ketamine may influence the concentrations of superoxide radicals by various mechanisms: neutralization via directly reducing the concentration of superoxide radicals, reduction of the superoxide synthesis by stimulating the glutathion peroxidase enzyme (30), and suppression of the neutrophils. Weiss et al. believe that ketamine cannot have an important influence on the first mechanism above due to its chemical structure, which includes a phenol component (30). Regarding the third mechanism above, ketamine has been shown to inhibit neutrophils and reduce neutrophil-derived superoxide radicals in coronary bypass grafting under in vivo and in vitro conditions (30-32). Similarly, ketamine has been found to reduce the adhesion of exogenously delivered human neutrophils in the guinea pig heart during ischemia-reperfusion (33). Moreover, ketamine has been observed to inhibit neutrophil adhesion in the rat mesentery, possibly due to suppression of E-selectine which is known to be an adhesion molecule activated by cytokines (34). In summary, based on our results and those of others, ketamine probably reduces lipid peroxidation by neutrophil suppression in rats with obstructive jaundice. Regarding histopathologic damage in this model, although portal polymorphonuclear leukocytes and necrosis scores were lower in the ketamine group, the scores were not significantly different from the other groups.

In this study, both ketamine and propofol provided better control over oxidative stress in rats with obstructive jaundice compared to pentobarbital and fentanyl.

Propofol (2, 6-diisopropylphenol) and thiopental are highly lipid-soluble anaesthetics and have antioxidant activities, protecting against lipid peroxidation (35). Both are often used to reduce cerebral edema during liver transplantation in fulminant hepatic failure patients (36-37). To date, the question of whether 
the antioxidant activities of propofol and thiopental were able to protect the liver from oxidative stress in the setting of biliary obstruction had not been asked.

Propofol is widely used for the induction and maintenance of general anesthesia, as well as for sedation of intubated postoperative patients on mechanical ventilation. Propofol has been proven to ameliorate ischemic/reperfusion injury in several organs, including the heart (38), lungs (39), brain (40), and kidney (41).

Although a few cases of acute hepatic failure linked to propofol have been reported (42), propofol has been found to limit oxidative injury in the liver and other tissues (43). Its effects on hepatic injury due to obstructive jaundice had not been examined until the current study.

While ketamine caused the most remarkable reduction in MDA levels, propofol's effect was not significantly different from that of ketamine. The propofol group had significantly higher SOD levels than the ketamine group. Propofol group had significantly lower CAT activities compared to the ketamine group. However, there was no significant difference between the propofol and other anesthetic groups. Regarding the histopathologic score, the propofol gorup had the second best score after the ketamine group, demonstrating that propofol stimulated oxidative stress in this rat model of obstructive jaundice to a lesser degree than thiopental and fentanyl. This may be due to inhibition of neutrophil migration.

Since in vitro studies have shown that propofol has antioxidant effects, reacts with toxic oxygen radicals and is transformed into phenoxyl radical, propofol may be showing its above mentioned impact over MDA by reducing the amount of toxic oxygen radicals (44), because the chemical structure of propofol is close to that of the vitamin E, an antioxidant (45). In view of the current data, the lower MDA levels in the propofol group may be explained by its antioxidant effect. In other studies, propofol has been specifically shown to increase antioxidant capacity in rat erythrocytes, lungs, liver, and heart by in vivo studies (46). The increase in the antioxidant capacity with propofol is believed to be secondary to the acquisition of an electron by propofol from SOR and its transformation into a more stable by-product $(46,47)$. Erythrocytes demonstrate elevated antioxidant capacity when exposed to propofol in in vivo and in vitro studies, which indicates that its antioxidant effect arises from the direct influence of the drug without any need of mediators. In addition, propofol has been shown to modify glutathion-related antioxidant systems in several studies (48). The positive effects of propofol, as shown in our study, can not be attributed to its intralipid carrier, because its carrier was found to have no antioxidant capacity in several studies $(49,50)$.

Thiopental is a highly lipid soluble anaesthetic which has demonstrated antioxidant properties by inhibiting lipid peroxidation $(51,52)$ and to a lesser degree, antihemolytic activity by inhibiting free-radical-mediated hemolysis of red blood cell in vitro $(53,54)$. In one study, at clinically relevant concentrations, thiopental significantly reduced reactive oxygen species production of neutrophils (54). Thiopental has been shown to act as an antioxidant by inhibiting MDA formation in vitro $(52,55)$. In a study by Almaas et al., thiopental inhibited iron-stimulated, but not the peroxynitrite-stimulated, MDA formation in vitro (52). The effect of thiopental on lipid peroxidation and free radicals in vivo may thus be a result of additional mechanisms than those suggested by in vitro experiments.

Previous studies have shown that thiopental alters hepatic function (56); for example, low- and single-dose thiopental are known to have no effect on the liver enzymes, but influence liver enzymes when applied at high and continuous doses $(57,58)$. As noted in various studies, high-dose intravenous anesthetics can lead to serious hepatic dysfunction (59). In our study, MDA was observed to reach its highest levels in the thiopental group, levels significantly higher than those of the ketamine and propofol groups. CAT activities were lowest in the thiopental group. Although not statistically significant, thiopental had the worst histopathologic score in terms of polymorphonuclear leukocytes and necrosis than any of the groups.

Protection by opioid receptor agonists against ischemia-reperfusion injury has been demonstrated during the last several years (60). Fentanyl is one of many opioid receptor agonists and has effects on the brain, heart, and liver $(61,62)$. Regarding its effects in obstructive jaundice however, little is known. In our study, the fentanyl group had significantly higher MDA levels compared to the ketamine group. CAT activities were significantly higher in the fentanyl group compared to the ketamine group only, however, SOD activities were similar between the groups.

Hepatocyte injury during cholestasis is due partly to the release of proinflammatory mediators that cause polymorphonuclear leukocytes to accumulate in the liver and become activated to damage hepatocytes (63). Infiltration by polymorphonuclear leukocytes may represent a source of liver injury during acute biliary obstruction in rats with bile duct ligation. In addition to sinusoids, neutrophils adhere in portal and postsinusoidal venules and extravasate from these locations $(64,65)$. In our study, although the ketamine group had the best score regarding portal polymorphonuclear leukocytes and necrosis, its scores were not significantly better than the other drugs.

Among the agents tested, ketamine and propofol generated the least amount of oxidative stress in this rat model of hepatic jaundice created by common bile duct ligation. They also demonstrated the strongest protective effect as measured by portal polymorphonuclear leukocytes and necrosis. Ketamine exhibited a stronger effect than propofol, as demonstrated by the lower levels of MDA in the ketamine-treated animals.

\section{References}

1. Sikuler E, Buchs AE, Yaari A, Keynan A. Hemodynamic characterization of conscious and ketamine anesthetized bile duct ligated rats. Am J Physiol 1991; 260: G161-166.

2. Tsai LY, Lee KT, Tsai SM. Changes of lipid peroxide levels in blood and liver tissue of patients with obstructive jaundice. Clin Chim Acta 1993; 215: 41-50.

3. Tsai LY, Tsai SM. Vitamin E levels in plasma and liver tissue of patients with cholelithiasis. J Biomed Lab Sci 1993; 5: 27-33.

4. Tsai LY, Lee KT, Tsai SM, Lu FJ. The role of lipid peroxidation and antioxidants in animals with obstructive jaundice. J Biomed Lab Sci 1995; $7: 1-8$. 
5. Halliwell B, Groofveld M. Oxygen toxicity, oxygen radicals, transition metals and disease. Biochem $\mathrm{J}$.

6. Murphy PG, Bennett JR, Myers DS, Davies MJ, Jones JG. The Effect ofPropofol Anesthesia on Free Radical-Induced Lipid Peroxidation in the Rat Liver. Eur J Anaesthesiol 1993; 10 (4): 261-266.

7. Fassoulaki A, Andreopoulou K, Williams G, Pateras C. The Effect of Single and Repeated Doses of Thiopentone and Fentanyl on Liver Function in the Rat. Anaesth Intensive Care 1986; 14 (2): 145-147.

8. Okutomi T, Nomto K, Nakamura K, Goto F. Autogenous Production of Hydroxyl Radicals From Thiopental. Acta Anaesthesiol Scand. 1995; 39 (3): 338-342.

9. Abidova, S.S. The Effects of Propofol and Ketamine on the Lipid Metabolism and Peroxidation in Rats. Klinicheskaya Farmakologiya 2002; 65 (6): 48.

10. Kevin LG, Novalija E, Stowe DF. Reactive oxygen species as mediators of cardiac injury and protection: the relevance to anesthesia practice. Anesth Analg 2005; 101 (5): 1275-1287.

11. Lee E. The effect of obstructive jaundice on the migration of reticuloendothelial cells and fibroblasts into early experimental granulomata. $\mathrm{Br}$ J Surg1972; 59: 875-877.

12. Fridovich I. Superoxide radical: an endogenous toxicant. Annu Rev Pharmacol Toxicol 1983; 23: 239-257.

13. Beutler E. Red Cell Metabolism. 2nd ed. New York: Grune \& Stratton, 1975 .

14. Ohkawa H, Ohishi N, Tagi K. Assay for lipid peroxides in animal tissues by thiobarbituric acid reaction. Anal Biochem 1979; 95: 351-358.

15. Lowry OH, Rosebrough NJ, Farr AL, Randall RJ. Protein measurement with the folin phenol reagent. J Biol Chem 1951; 193: 265-725.

16. Singh S, Shackleton G, Ah-Sing E, Chakraborty J, Bailey ME. Antioxidant defenses in the bile duct-ligated rat. Gastroenterology 1992; 103: 1625-1629.

17. Alptekin N, Mehmetcik G, Uysal M, Aykac-toker G. Evidence for oxidative stress in the hepatic mitochondria of bile duct ligated rats. Pharmacol Res 1997; 36: 243-247.

18. Stephen B, Kyle L, Yong X, Cynthia A, Donald E, Earl F, James E. Role of Oxidative Stres in the :Mechanism of Dieldrin's Hepatotoxicity. Annals of Clinical and Laboratory Science 1997; 27 (3): 196-208.

19. Atiba JO, Horai Y, White PF, Trevor AJ, Blaschke TF, Sung ML. Effect of etomidate on hepatic drug metabolism in humans. American Society for Pharmacology and Experimental Therapeutics 1995; 13 (3): 364-367.

20. Fee JPH, McCaugghey W. Clarke RSJ, Wllace WFM. Sedative Drugs. In: Anaesthetic Physiology and Pharmacology. New York: Churchill Livingston, 1997; 191-206.

21. Cooperman LH, Warden JC, Price HL. Splanchnic Circulation During Nitrous Oxide Anaesthesia and Hypocarbia in Normal Man. Anesthesiology 1968; 29: 254-258.

22. Price HL, Deutsch S, Cooperman LH et al. Splanchnic Circulation During Cyclopropane Anesthesia in in Normal Man. Anesthesiology 1965; 26: 312-319.

23. Yildiz S, Arici C, Erdogan O, Pestereli E, Gelen T, Demirbas A, Emek K. Parsiyel hepatektomi yapilan ratlarda enteral ve parenteral beslenmenin farkli formlarinin karaciger fonksiyonlari ve rejenerasyonu üzerine etkisi. Ulusal Cerrahi Dergisi 2001; 17 (2): 75-81.

24. Gülben K, Mersin H, Irkkan C, Berberoglu U. Deneysel parsiyel hepatektomi modelinde pentagastrinin karaciger rejenerasyonuna etkisi. Ulusal Cerrahi Dergisi 2002; 18 (3): 134-139..
25. Reeker W, Werner C, Möllenberg O, Mielke L, Kochs E. Highdose $\mathrm{S}(+)$-ketamine improves neurological outcome following incomplete cerebral ischemia in rats. Can J Anaesth 2000; 47: 572-578.

26. Lee HT, Ota-Setlik A, Fu Y, Nasr SH, Emala CW. Differential protective effects of volatile anesthetics against renal ischemia reperfusion injury in vivo. Anesthesiology 2004; 101: 1313-1324.

27. Salman AE, Dal D, Salman MA, Iskit AB, Aypar U. The effect of ketamine on acute muscular ischaemia reperfusion in rats. Eur J Anaesthesiol 2005; 22: 712-716.

28. Kato R, Foex P. Myocardial protection by anesthetic agents against ischemia-reperfusion injury: an update for anesthesiologists. Can J Anaesth 2002; 49: 777-791.

29. Camara CR, Guzman FJ, Barrera EA, Cabello AJ, Garcia A, Fernandez NE et al. Ketamine anesthesia reduces intestinal ischemia/reperfusion injury in rats. World J Gastroenterol 2008; 14: 5192-5196.

30. Weiss M, Birkhahn A, Mettler S. Stereoselective suppression of neutrophil function by ketamine. Immunopharmacol Immunotoxicol 1995; 17: (1): 91-107

31. Weigand MA, Schmidt H, Zhao Q. Ketamine Modulates the Stimulated Adhesion Molecule Expression on Human Neutrophils In Vitro. Anesth Analg 2000; 90: 206-212.

32. Zilberstein G, Levy R, Rachinsky M. Ketamine attenuates neutrophil activation after cardiopulmonary bypass. Anesth Analg 2002; 95: 531-536.

33. Szekely A, Heindl B, Zahler S. Nonuniform Behavior of Intravenous Anesthetics on Postischemic Adhesion of Neutrophils in the Guinea Pig Heart. Anesth Analg 2000; 90: 1293-1300.

34. Miller LS, Morita Y, Rangan U. Supression of cytokine- induced neutrophil accumulation in rat mesenteric venules in vivo by general anesthesia. Int J Microcirc Clin Exp 1996; 16: (3): 147-154.

35. Almaas R, Saugstad OD, Pleasure D, Rootwelt T. Effect of barbiturates on hydroxyl radicals, lipid peroxidation, and hypoxic cell death in human NT2-N neurons. Anesthesiology 2000; 92: 764-774.

36. Forbes A, Alexander GJ, O'Grady JG, Keays R, Gullan R, Dawling $\mathbf{S}$ et al. Thiopental infusion in the treatment of intracranial hypertension complicating fulminant hepatic failure. Hepatology 1989; 10: 306-310.

37. Jalan R. Pathophysiological basis of therapy of raised intracranial pressure in acute liver failure. Neurochem Int 2005; 47: 78-83.

38. Lim KH, Halestrap AP, Angelini GD, Suleiman MS. Propofol is cardioprotective in a clinically relevant model of normothermic blood cardioplegic arrest and cardiopulmonary bypass. Exp Biol Med 2005; 230: $413-420$

39. Balyasnikova IV, Visintine DJ, Gunnerson HB, Paisansathan C, Baugluman VL, Minshall RD et al. Propofol attenuates lung endothelial injury induced by ischemia-reperfusion and oxidative stress. Anesth Analg 2005; 100: 929-936.

40. Ergun R, Akdemir G, Sen S, Tasci A, Ergungor F. Neuroprotective effects of propofol following global cerebral ischemia in rats. Neurosurg Rev 2002; 25: 95-98.

41. Wang HH, Zhou HY, Chen CC, Zhang XL, Cheng G. Propofol attenuation of renal ischemia/reperfusion injury involves heme oxygenase-1. Acta Pharmacol Sin 2007; 28 (8): 1175-1180.

42. Kneiseler G, Bachmann HS, Bechmann LP, Dechene A, Heyer T, Baba H, Saner F, Jochum C, Gerken G, Canbay A. A Rare Case of Propofol-Induced Acute Liver Failure and Literature Review. Case Rep Gastroenterol 2010; 4 (1): 57-65. 
$139-144$

43. Lin LN, Wang WT, Wu JZ, Hu ZY, Xie KJ. Protective effect of propofol on liver during ischemia-reperfusion injury in patients undergoing liver surgery. Zhongguo Wei Zhong Bing Ji Jiu Yi Xue 2004; 16: 42-44.

44. Kahraman S, Kilinc K, Dal D. Propofol attenuates formation of lipid peroxidases in tourniquet induced ischemia-reperfusion injury. $\mathrm{Br} \mathrm{J}$ Anesth 1997; 78; 279-281.

45. Aldemir O, Celebi H, Cevik C. The effects of propofol or halothane on free radical production after tourniquet induced ischeia-reperfusion injury during knee arthroplasty. Acta Anesthesiol Scan 2001; 45: 1221-1225.

46. Runzer TD, Ansley DM, Godin DV. Tissue Antioksidant Capasity During Anesthesia: Propofol Enhances In Vivo Red Cell and Tissue Antioxidant Capasity in a rat Model. Anesth Analg 2002; 94: 89-93.

47. Mouithys-Mickalad A, Hans P, Deby-Dupont G. Propofol reacts with peroxynitrite to form a phenoxyl radical: demonstration by electron spin resonans. Biochem Biophys Res Commun 1998; 249: 833-837.

48. De La Cruz JP, Sedeno G, Carmona A. The in vitro effects of propofol on tissular oxidative stress in the rat. Anesth Analg 1998; 87: 1141-1146.

49. Ansley DM, Lee J-U, Godin VD. Propofol enhances red cell antioxidant capacity in swine and humans. Can J Anaesth 1998; 45: 233-239.

50. Mathy-Hartert M, Deby-Dupont G, Hans P. Protective activity of propofol, Diprivan, and intralipid against active oxygen species. Mediators Inflamm 1998; 7: 327-333.

51. Demopoulos HB, Flamm ES, Seligman ML et al. Antioxidant effects of barbiturates in model membranes undergoing free radical damage. Acta Neurologica Scand 1977; 56: 152-153.

52. Almaas R, Saugstad OD, Pleasure D et al. Effects of barbiturates on hydroxyl radicals, lipid peroxidation, and hypoxic cell death in human NT2-N neurons. Anesthesiology 2000; 92: 764-774.

53. Murphy PG, Atkinson R, Columb MO et al. Effect of propofol and thiopentone on free radical-induced haemolysis. Br J Anaesth 1992; 69: 532P-533P.

54. Murphy PG, Davies MJ, Columb MO et al. Effect of propofol and thiopentone on free radical mediated oxidative stress of the erythrocyte. Br J Anaesth 1996; 76: 536-453.
55. Smith DS, Rehncrona S, Siesjo“ BK. Inhibitory effects of diferent barbiturates on lipid peroxidation in brain tissue in vitro. Anesthesiology 1980; 53: 186-194.

56. Novelli GP, Marsili M, Lorenzi P. Influence of Liver Metabolism on the Actions of Althesin and Thiopentone. Br J Anaesth 1975; 47 (9): 913-916.

57. Blunnie WP, Zacharias M, Dundee JW, et al. Liver Enzyme Studies with Continuous Intravenous Anaesthesia. Anahesthesia1981; 36 (2): $152-156$.

58. Fassoulaki A, Andreopoulou K, Williams G, Pateras CH. The Effect of Single andRepeated Doses of Thiopentone and Fentanyl on Liver Function in the Rat. Anahesthesia Intens Care 1986; 14 (2): 145-147.

59. Okutomi T, Nomto K, Nakamura K, Goto F. Autogenous Production of Hydroxyl Radicals From Thiopental. Acta Anaesthesiol Scand 1995; 39 (3): $338-342$.

60. Mayfield KP, D'Alecy LG. Role of endogenous opioid peptides in the acute adaptation to hypoxia. Brain Res 1992; 582: 226-231.

61. Chinev S, Bakalova R, Peneva V, Uzunova P, Galabova T, Sokolova Z, Ribarov S. Nitrous oxide with fentanyl and droperidol minimizes lipid peroxidation in the liver. Eur J Anaesthesiol 1995; 12 (2): 155-162.

62. Kil HY, Oh WS, Han TH. Fentanyl alters cytokine level during global cerebral ischaemia/reperfusion in rats. Eur J Anaesthesiol: European Society of Anaesthesiologists; 8th Annual Meeting with the Austrian International Congress; Vienna, Austria, 1-4 April 2000 (17): 90.

63. Aldana PR, Goerke ME, Carr SC, Tracy TF Jr. The expression of regenerative growth factors in chronic liver injury. J Surg Res 1994; 57: 711-717.

64. Koeppel TA, Trauner M, Baas JC, Thies JC, Schlosser SF, Post S, Gebhard MM, Herfarth C, Boyer JL, Otto GE. Extrahepatic biliary obstruction impairs microvascular perfusion and increases leukocyte adhesion in rat liver. Hepatology 1997; 26: 1085-1091.

65. Saito JM, Maher JJ. Bile duct ligation in rats induced biliary expression of cytokine-induced neutrophil chemoattractant. Gastroenterology 2000; 118: 1157-1168. 